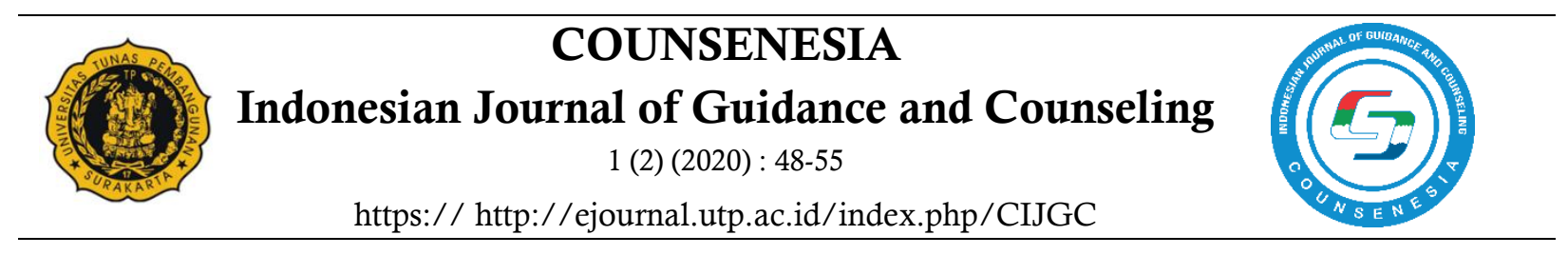

\title{
MENINGKATKAN PSYCHOLOGICAL WELL-BEING MELALUI CINEMA EDUCATION SEBAGAI UPAYA MENGHADAPI AGING POPULATION
}

\author{
Rahmaniar Rizky ${ }^{1}$, Tyas Martika Anggriana², Noviyanti Kartika Dewi ${ }^{3}$ \\ 1,2,3 Universitas PGRI Madiun \\ Email: rahmaniar71@gmail.com
}

\begin{abstract}
Info Artikel
Abstrak

Riwayat Artikel

Diterima:

Oktober 2020

Disetujui:

Desember 2020

Publikasi:

Desember 2020

Psychological well-being merupakan keadaan dimana individu dapat menyeimbangkan potensi dalam dirinya secara optimal. Tujuan dari penelitian adalah untuk mengetahui ada tidaknya peningkatan psychological well-being sebelum dan sesudah diberikan cinemaeducation sebagai upaya preventif menghadapi aging population di Desa Mangkujayan, Kecamatan Ponorogo, Kabupaten Ponorogo. Desain penelitian yang digunakan dalam penelitian ini adalah yaitu one-group pretest-post test design. Teknik pengumpulan data yang digunakan dalam penelitian ini yaitu dengan menggunakan kuesioner, yang merupakan instrument pengumpulan data yang berisikan pernyataan atau pertanyaan yang diberikan oleh peneliti, yang selanjutnya diisi langsung oleh responden. Teknik analisis data dengan menggunakan Uji Wilcoxon melalui aplikasi SPSS 16. Hasil melalui Uji Wilcoxon menunjukkan signifikan $<0.05$ yaitu 0.005 dan dapat dikatakan bahwa hipotesis diterima sehingga layanan cinema education dapat meningkatkan psychological well-being sebagai upaya preventif menghadapi aging population di Desa Mangkujayan Kecamatan Ponorogo Kabupaten Ponorogo tahun 2020.
\end{abstract}

Kata Kunci: aging population, cinema education, psychological well-being

\begin{abstract}
Psychological well-being is a condition where individuals can balance their potential optimally. The purpose of this was to determine whether there was an increase in psychological well-being before and after being given treatment as a preventive to face the aging population in Mangkujayan Village, Ponorogo District, Ponorogo Regency. The research design in this study was a one-group pretest-post test. The sampling technique of this research is purposive sampling. The data collection technique used in this research is questionnaire, which is a data collection instrument that contains statements or questions which are then filled in by the respondent. The data analysis techniques using Wilcoxon Test through the SPSS 16 application. The results through the Wilcoxon Test show significant $<0.05$, namely 0.005 and it can be said that the hypothesis is accepted so that cinema education services can improve psychological well-being as a preventive effort to face the aging population in Mangkujayan Village, Ponorogo District, Ponorogo Regency in 2020.
\end{abstract}

Keywords: cognitive restructuring techniques, social anxiety

(C) 2020 Universitas Tunas Pembangun Surakarta

ISSN: 2746-3532 (Online) 


\section{PENDAHULUAN}

Ketika individu memasuki usia 65 tahun maka individu masuk ke masa dewasa akhir. Individu yang masuk dalam masa dewasa akhir biasa disebut dengan orang lanjut usia atau dapat juga disebut lansia. Berdasarkan data yang diperoleh dari BPS pada tahun 2010 jumlah lansia di Indonesia ada sebanyak 18 juta orang. Pada 2045 jumlah lansia dapat mengalami penambahan jumlah sekitar 56,99 juta orang. Berdasarkan hasil Supas 2015 menunjukkan 4 provinsi dengan presentase penduduk lanjut usia tertinggi yaitu Daerah Istimewa Yogyakarta mencapai 13,6\%, Jawa Tengah mencapai 11,7\%, Jawa Timur mencapai 11,5\%, dan Bali sebesar 10,4\% (dalam Cicih, 2019). Penambahan jumlah lansia tersebut dikarenakan jumlah kelahiran yang semakin sedikit sedangkan angka harapan hidp semakin tinggi.

Seiring dengan penambahan jumlah lanisa maka akan muncul berbagai problem terkait dengan perkembangan lansia tersebut. Seperti masa-masa perkembangan yang lain tentu terdapat perubahan ketika individu memasuki masa dewasa akhir, baik itu perubahan secara fisik, emosional dan kognitifnya. Dikarenakan adanya perubahan dan penurunan fungsi fisik, emosi dan kognitifnya tersebut maka lansia diharapkan dapat mengurangi aktifitas yang dinilai berat dan memanfaatkan waktu yang ada untuk kegiatan yang lebih bermanfaat dan membawa kebahagiaan pada diri lansia. Selain adanya perubahan dan penurunan fungsi baik fisik, emosi dan kognitif, lansia juga mengalami gangguan dalam masa perkembangannya dimana harapan yang diinginkan tidak sesuai dengan kenyataan yang ada.

Menurut Nurzainun (2018) terdapat beberapa gangguan psikis yang dialami oleh lansia diantaranya kecemasan, ketakutan, kesepian, mudah tersinggung dan banyak menuntut. Seiring dengan bertambahnya jumlah lansia dan dengan berbagai macam gangguan lansia yang sebelumnya telah dijabarkan penjelasannya maka hal ini dapat memicu timbulnya masalah-masalah pada lansia di Indonesia. Gangguan psikis yang dialami oleh lansia dapat memunculkan stress yang nantinya juga dapat mempengaruhi kesehatan mental serta fisik lansia. Beberapa permasalahan tersebut dapat mempengaruhi kesehatan mental lansia dan menyebabkan psychological well-being pada lansia menjadi kurang. Psychological well-being merupakan istilah yang digunakan untuk menggambarkan kesehatan psikologis seseorang yang didasarkan pada pemenuhan kriteria fungsi psikologi positif. Atau dapat dikatakan sebagai pencapaian dari potensi psikologis individu. Potensi itu diantaranya adalah penerimaan diri individu, bagaimana individu membentuk hubungan yang baik dengan individu lain dan lingkungan sekitar, dapat mengambil keputusan yang baik dan mandiri, memiliki kompetensi untuk mengatur lingkungannya, individu dapat menentukan tujuan hidup, dan individu merasa mampu untuk melalui tahap perkembangan dalam kehidupannya. Berdasarkan penelitian yang dilakukan oleh Mailisa dan Khairani (2017) mengenai gambaran psychological well-being pada lansia menunjukkan beberapa dimensi dalam kategori baik namun juga ada beberapa dimensi yang masuk dalam kategori kurang baik. Penelitian lain yang dilakukan oleh Levy (2018) menemukan fakta bahwa individu yang memiliki pandangan positif soal menjadi tua hidup dengan waktu yang lebih panjang dan juga lebih baik.

Individu yang memiliki pandangan positif tidak rentan terhadap depresi dan kecemasan. Selain fakta dari penelitian ini, apabila survey-survey yang telah dilakukan kemudian dikorelasikan terdapat analisis yang menyatakan bahwa semakin tinggi level respek, maka semakin tinggi tingkat psychological well-being lansia di daerah tersebut. Dari hasil penelitian diatas diperlukan adanya upaya peningkatan psychological well-being pada lansia. Saat ini fenomena aging population sudah terjadi di Indonesia. Oleh sebab 
itu, bentuk dukungan positif apapun yang dapat dilakukan untuk meningkatkan psychological well-being diperlukan. Disini peran bimbingan dan konseling juga dapat membantu dalam upaya tersebut. Bimbingan dan konseling dapat mengimplementasikan teknik cinema-education dengan menggunakan format bimbingan kelompok. Metode ini dinilai sebagai treatment yang tepat untuk meningkatkan psychological well-being pada lansia. Cinema-education ini dapat menambah wawasan baru untuk para penontonnya. Tujuan dari penelitian ini adalah untuk mengetahui ada tidaknya peningkatan psychological well-being melalui cinema-education sebagai upaya preventif dalam menghadapi aging population di Desa Mangkujayan, Kecamatan Ponorogo, Kabupaten Ponorogo Tahun 2020.

Pengertian dari psychological well-being adalah keadaan dimana individu dapat menyeimbangkan atau mengontrol emosi positif dan negatif dalam diri sendiri sehingga individu dapat memanfaatkan potensi dalam dirinya secara optimal untuk menuntaskan tugas-tugas perkembangannya. Ryff (dalam Ruini dan Fava, 2014) mendefinisikan psychological well-being sebagai sebuah kondisi dimana individu memiliki sikap yang positif terhadap diri sendiri dan orang lain, dapat mengatur lingkungannya, dapat membuat keputusan sendiri, dapat mengembangkan diri dan juga dapat menentukan tujuan hidup. Dalam psychological well-being terdapat beberapa dimensi diantaranya adalah Penguasaan lingkungan, Pertumbuhan pribadi, Tujuan dalam hidup, Otonomi dan Penerimaan diri, Hubungan positif dengan orang lain. Disetiap dimensi ini setiap individu memiliki tingkat yang berbeda sehingga dari setiap dimensi dapat diketahui individu memiliki tingkat psychological well-being yang rendah atau tinggi. Adapun factor-faktor yang mempengaruhi psychological well-being menurut De Lazzari (dalam Hutapea, 2011) antara lain adalah faktor demografi, kepribadian, dukungan sosial dan evaluasi terhadap pengalaman hidup.

Menurut Rahmawati (2014) film (Cinema) disebut juga gambar hidup (Motion Pictures), yaitu serangkaian gambar diam (Still Pictures) yang meluncur secara cepat dan diproyeksikan sehingga menimbulkan kesan hidup dan bergerak. Film merupakan media yang menyajikan pesan audiovisual dan gerak. Dalam bidang terapi terdapat teknik yang disebut cinema therapy. Menurut pendapat Tomb (2003) cinema therapy adalah intervensi terapeutik yang memungkinkan klien menilai secara visual karakter-karakter yang ada dalam film berinteraksi dengan orang lain, lingkungannya dan masalah-masalah pribadinya. Intervensi ini bertujuan untuk mendorong perkembangan terapeutik secara positif. Cinema theraphy adalah sebuah intervensi terapeutik yang membiarkan klien secara visual mengkaji interaksi antar karakter, lingkungan-lingkungan dan isu-isu personal dalam sebuah film yang bertujuan mendorong perkembangan terapeutik secara positif. Cinema Theraphy telah muncul sebagai intervensi berkhasiat untuk orang dewasa, remaja dan anak-anak. dengan melihat dan mendiskusikan film, konseli dan terapis dapat mengakses makna metaforis konten untuk proses pekerjaan termasuk didalamnya belajar. Beberapa kelebihan sinema edukasi menurut Sapiana (2014) antara lain: a) terjadi kerja aktif dalam otak, b) membangkitkan semangat di alam bawah sadar, dan c) menemukan makna dan maksud dari alur film cerita. Selain itu menurut Cahyaningrum dkk (2018) menyebutkan bahwa cinema education ini juga bermanfaat sebagai media atau produk yang bersifat preventif karena dalam implementasinya lebih relevan untuk digunakan oleh konselor untuk mengisi bimbingan dan konseling.

Dalam penelitian ini cinema-education yang digunakan terinspirasi dari teknik cinema theraphy yang kemudian cinema atau film yang ditayangkan digunakan sebagai media edukasi sehingga disebut cinema-education. Oleh karena itu dalam penelitian ini teknik 
yang digunakan merupakan cinema-education. Cinema-education ini dapat digunakan sebagai katarsis yaitu dengan memanfaatkan pemutaran film yang memiliki kaitan dengan permasalahan yang sedang dihadapi subjek penelitian sehingga subjek dapat mendapatkan edukasi dan juga dapat melepas emosi yang dirasakan.

BKKBN (2019) menyatakan bahwa aging population ini dapat masuk pada salah satu fenomena dimana beberapa pengoptimalan program BKKBN berhasil. Kegaiatn berhasil yang dimaksud adalah penurunan tingkat kematian bayi, perbaikan akses terhadap pendidikan, dan semakin terjaminnya fasilitas kesehatan. Hal ini sependapat dengan penjelasan United Nation (dalam Heryanah, 2010) aging population merupakan sebuah fenomena yang terjadi apabila umur median dari suatu daerah atau negara mengalami peningkatan. Peningkatn tersebut terjadi karena bertambahnya tingkat harapan hidup. Hal lain yang terjadi saat harapan hidup meningkat adalah menurunnya tingkat fertilitas. Dan aging population terjadi apabila jumlah populasi usia lanjut berada pada lebih dari tujuh persen. Sehingga dapat disimpulkan bahwa aging population terjadi apabila angka harapan hidup di suatu daerah atau negara meningkat hingga melebihi tujuh persen. Disisi lain saat angka harapan hidupnya meningkat maka angka fertilitas menurun. Namun masih terdapat hal-hal positif yang terjadi seperti semakin terjaminnya fasilitas kehidupan.

\section{METODE}

Penelitian ini menggunakan desain penelitian experiment one-group pretest-post test. Peneliti menggunakan desain penelitian ini dikarenakan penelitian yang akan dilakukan bertujuan untuk membandingkan hasil yang didapatkan sebelum dan sesudah diberikan treatment. Populasi dalam penelitian ini adalah seluruh anggota Bina Keluarga Lansia (BKL) Sakinah Desa Mangkujayan Kecamatan Ponorogo Kabupaten Ponorogo yang berjumlah 30 orang dan berusia rata-rata 55 hingga 75 tahun. Dalam penelitian ini teknik sampling yang digunakan adalah porpusive sampling. Peneliti memilih teknik purposive sampling karena peneliti hanya akan mengambil sampel dari lansia yang memiliki tingkat psychological well-being yang rendah, sehingga penelitian ini dapat dilakukan tepat sesuai dengan tujuan penelitian.

Adapun teknik pengumpulan data yang digunakan dalam penelitian ini menggunakan skala psikologis psychological well-being. Indikator dalam skala psikologis tersebut diantaranya adalah penguasaan lingkungan, pertumbuhan pribadi, tujuan hidup, otonomi, penerimaan diri, dan hubungan positif dengan orang lain Jumlah item dalam skala tersebut adalah 51 item. Sedangkan teknik analisis yang digunakan dalam penelitian ini adalah melalui pengujian Wilcoxon dengan berbantu aplikasi SPSS. 16.0.

\section{HASIL DAN PEMBAHASAN}

Penelitian yang dilakukan kepada 30 orang anggota Bina Keluarga Lansia (BKL) Sakinah Desa Mangkujayan Kecamatan Ponorogo Kabupaten Ponorogo ini dilakukan dengan memberikan 4 kali treatment (perlakuan). Hal ini dilakukan untuk mengetahui bagaimana tingkat psychological well-being anggota BKL setelah mendapatkan layanan bimbingan cinema-education. Adapun tahapan kegiatan yang dilakukan peneliti antara lain:

1. Pada pertemuan pertama peneliti memberikan penjelasan terkait cinema-education dan psychological well-being terlebih dahulu dengan tujuan agar anggota BKL memahami apa yang akan dilakukan. 
2. Pada pertemuan kedua peneliti mulai mengaplikasiskan bimbingan melalui cinemaeducation dengan 2 dimensi yaitu dimensi penguasaan lingkungan dan otonomi.

3. Pada pertemuan ketiga peneliti melanjutkan dengan menampilkan cinema dengan 2 dimensi lainnya yaitu tentang tujuan dalam hidup dan pertumbuhan pribadi.

4. Pada pertemuan keempat sampel menonton cinema dengan dimensi penerimaan diri dan hubungan positif dengan yang lain. Pada pertemuan ini sampel menjadi lebih aktif untuk berdiskusi dan saling mendengarkan pendapat yang lain serta memberikan tanggapan

Setelah melakukan 4 kali treatment tersebut hasil penelitian yang dilakukan kepada anggota Bina Keluarga Lansia (BKL) Sakinah Desa Mangkujayan Kecamatan Ponorogo Kabupaten Ponorogo yang berjumlah 30 orang menunjukkan hasil sebagai berikut :

Tabel 1. Pre Test - Post Test Psychological Well-Being

\begin{tabular}{lcc}
\hline \multicolumn{1}{c}{ Dimensi } & Pre Test & Post Test \\
\hline Penguasaan Lingkungan & $67.50 \%$ & $80.00 \%$ \\
\hline Pertumbuhan Pribadi & $74.36 \%$ & $77.81 \%$ \\
\hline Tujuan Hidup & $74.06 \%$ & $79.69 \%$ \\
\hline Otonomi & $73.61 \%$ & $83.39 \%$ \\
\hline Penerimaan Diri & $77.22 \%$ & $86.67 \%$ \\
\hline Hubungan positif dengan orang lain & $71.67 \%$ & $85.30 \%$ \\
\hline
\end{tabular}

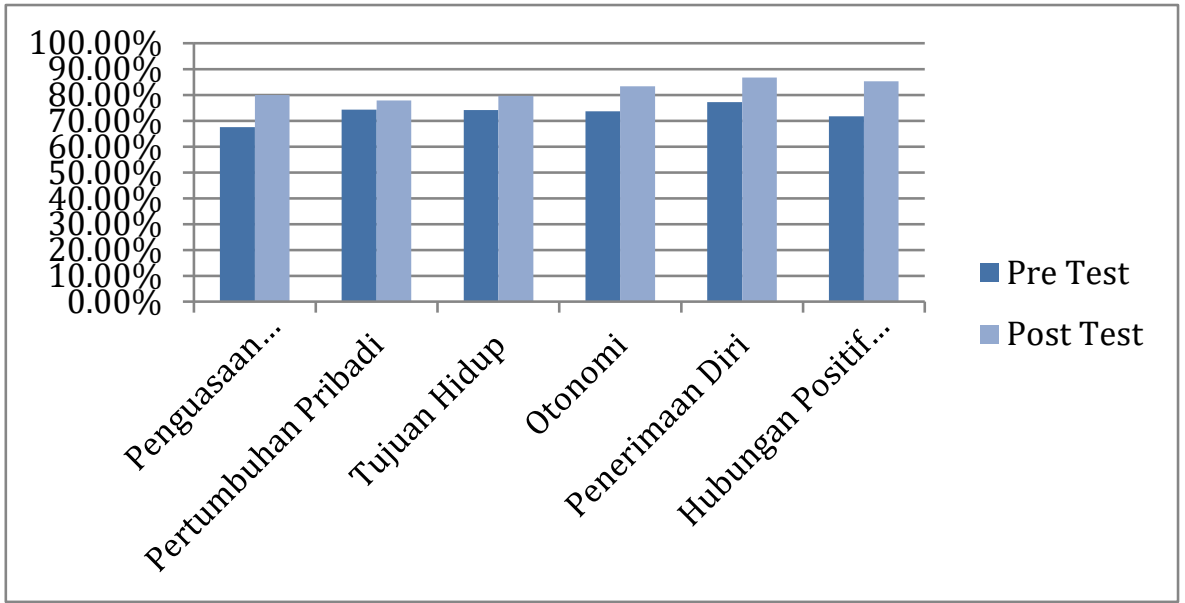

Dari pemaparan hasil diatas dapat dilihat melalui tabel bahwa pada setiap dimensi psychological well-being terdapat tingkat persentasi yang berbeda antara satu dengan lainnya. Dapat dilihat dari dimensi penguasaan lingkungan pada pretest tingkat persentasinya adalah sebanyak $67.50 \%$ dan meningkat menjadi $80 \%$ setelah diberikan perlakuan berupa cinema education sehingga terdapat peningkatan sebanyak $12.5 \%$. Pada dimensi pertumbuhan pribadi menunjukkan persentasi pretest $74.36 \%$ dan pada hasil pot test sebanyak $77.81 \%$ sehingga pada dimensi ini terjadi peningkatan persentasi yaitu $3.45 \%$. Lalu pada dimensi tujuan hidup terdapat peningkatan sebanyak $5.63 \%$ setelah diberikan perlakuan. Pada dimensi otonomi juga terdapat peningkatan sebesar $9.78 \%$ setelah sample mengikuti cinema education. Kemudian pada dimensi penerimaan diri terjadi peningkatan sebesar $9.45 \%$ dari $77.22 \%$ menjadi $86.67 \%$. Dan yang terakhir dimensi hubungan positif dengan oraang lain terjadi peningkatan sebesar $13.63 \%$.

Dengan demikian secara keseluruhan berdasarkan hasil analisis data menunjukkan bahwa terdapat perbedaan yang signifikan pada psychological well-being dimana adanya peningkatan dari sebelum sampel diberikan treatment/perlakuan dengan setelah sampel 
diberikan treatment/perlakuan melalui cinema-education. Adanya peningkatan pada nilai rata-rata dari sebelum dan sesudah diberikan perlakuan menandakan bahwa cinemaeducation dapat digunakan untuk meningkatkan psychological well-being anggota bina keluarga lansia (BKL) di Desa Mangkujayan Kecamatan Ponorogo Kabupaten Ponorogo Tahun 2020.

Masa lanjut usia (lansia) merupakan bagian akhir dari rentang kehidupan manusia, karena lansia merupakan tahapan akhir dari proses perkembangan manusia. Berdasarkan data dari kementrian sosial menyatakan bahwa jumlah lanjut usia (lansia) di Indonesia lebih dari $10 \%$ dari populasi penduduk pada 2020, hal ini berarti lebih dari 10,6\% jumlah penduduk Indonesia merupakan lansia (https://mediaindonesia.com). Darmawan (dalam Fauzan \& Qodariah, 2014) menjelaskan terdapat 3 masalah pokok yang dialami para lanjut usia, yaitu 1). Masalah yang disebabkan oleh perubahan hidup dan kemunduran fisik yang dialami oleh lanjut usia, 2). Lanjut usia sering mengalami kesepian uamh disebabkan oleh putusnya hubungan dengan orang-orang yang paling dekat dan disayangi, 3). Post power syndrome, hal ini biasanya dialami lanjut usia yang baru saja mengalami pensiun, kehilangan kekuatan, penghasilan dan kebanggan. Berkualitas tidaknya hidup lansia berkaitan dengan kesadaran lansia tersebut terhadap masalah kesehatan serta kebiasaan hidup sehat mereka. Kepuasan hidup bersifat sangat subyektif, tergantung pada bagaimana individu memandang hidupnya sendiri. Seligman (dalam Diener \& Scollon, 2003) menunjukkan bahwa semua orang yang paling bahagia adalah yang memiliki kualitas hubungan social yang dinilai baik.

Lebih lanjut berdasarkan hasil penelitian sebelumnya yang dilakukan oleh Hidayah (2014) terkait cinema-education menyebutkan bahwa cinema-education dapat digunakan untuk meningkatkan sikap asertif. Selain itu dalam penelitiannya ia juga mengungkapkan bahwa cinema-education dapat mengubah persepsi dan cara pandang individu sehingga pengalaman yang di dapat dari cinema-education tersebut memotivasi dan memberi inspirasi individu dalam menyikapi kehidupannya. Selain itu wawasan individu dan pengalaman menjadi meningkat meskipun tidak dilaluinya secara langsung namun individu jadi mempelajari hal baru.

Selain dampak dari pemberian cinema-education terdapat hal lain yang ditemukan oleh peneliti. Pada saat pengisian kuesioner sampel pun tanpa diminta juga memberikan informasi mengenai kehidupan mereka. Sampel senang untuk menceritakan pengalaman yang mereka dapatkan di masa muda. Contohnya pada saat mengisi item penilaian diri terdapat sampel yang menyatakan bahwa hanya orang lain yang dapat menilai dirinya. Lalu pada item menghabiskan waktu dengan cucunya terdapat sampel yang menjelaskan bahwa sampel memiliki kegiatan lain sehingga dapat dilihat bahwa lansia masih aktif untuk melakukan rutinitas selain bekerja. Hal lain yang dapat diamati adalah saat pengisian kuesioner tersebut respon peneliti dalam mendampingi sampel. Ketika peneliti mendengarkan dan menanggapi dengan sabar terhadap cerita yang disampaikan oleh sampel terlihat bahwa sampel merasa senang. Terdapat pula keadaan dimana lansia terlihat tidak suka pada beberapa item unfavorabel sehingga membuat lansia ini sensitive kepada hal yang didapatkan.

Dengan demikian dapat diketahui bahwa apabila kita berinteraksi dengan lansia harus dilakukan dengan hati-hati karena mereka lebih sensitive terhadap respon yang didapat. Fenomena aging population yang terjadi dapat dihadapi dengan baik oleh lansia apabila psychological well-being pada lansia tersebut memiliki tingkat yang tinggi. Pada penelitian ini telah terbukti bahwa cinema-education dapat meningkatkan psychological 
well-being. Sehingga untuk dapat menghadapi fenomena aging population dengan baik dapat diupayakan dengan program cinema-education.

\section{KESIMPULAN}

Berdasarkan dari penelitian yang telah dilaksanakan peneliti, dapat disimpulkan bahwa psychological well-being anggota BKL mengalami peningkatan setelah diberikan perlakuan melalui cinema education. Peningkatan tersebut terjadi disemua dimensi psychological well-being yaitu penguasaan lingkungan, pertumbuhan pribadi, tujuan hidup, otonomi, penerimaan diri dan hubungan positif. Layanan bimbingan cinema education digunakan sebagai upaya preventif dalam menghadapi aging population. Selain itu cinema education dapat digunakan sebagai alternatif dalam meningkatkan psychological well-being anggota bina keluarga lansia di Desa Mangkujayan Kecamatan Ponorogo Kabupaten Ponorogo. Lebih lanjut penelitian ini terbatas pada jumlah sampel yang relatif kecil dan tidak memperhatikan perbedaan jenis kelamin. Penelitian selanjutnya diharapkan dapat melibatkan jumlah sampel yang lebih besar dan latar belakang subjek penelitian yang bervariasi, memperhatikan perbedaan jenis kelamin dan melakukan penelitian secara longitudinal

\section{DAFTAR PUSTAKA}

BKKBN. 2018. Jurnal Keluarga: Peran BKKBN Di Balik Gerakan Penanggulangan Stunting. Jakarta Timur : BKKBN.

Cahyaningrum, Vesti Dwi dkk. 2018. Pengembangan Panduan Pelatihan Empati Menggunakan Teknik Sinema Edukasi untuk Mencegah Perilaku Bullying Siswa Sekolah Menengah Pertama. Jurnal Kajian Bimbingan dan Konseling Vol (3) No. 3

Cicih, L H M. 2019. Info Demografi. BKKBN.

Diener, Ed. (1984). Subjective well-being. Psychological Bulletin American Psychological, Inc, Vol. 95, No. 3, 542-575.

Fauzan, Hindun Handayani \& Qodariah, Siti. 2014. Studi Deskriptif Mengenai Subjective Well-Being pada Lansia di Panti Sosial Tresna Werdha Budi Pertiwi Bandung. PROSIDING PSIKOLOGI . Volume 3, No.1, Tahun 2017 ISSN: 2460-6448

Fava, G A \& Ruini, C. 2014. Increasing Psychological Well-Being In Clinical And Educational Settings. Amerika Serikat : Springer Science

Heryanah. 2015. Aging Population Dan Bonus Demografi Kedua Di Indonesia. Sukabumi : Badan Pusat Statistik.

Hidayah, Nur. 2014. Keefektifan Teknik Sinema Edukasi Untuk Meningkatkan Sikap Asertif Siswa MTs Negeri Malang I. Malang : Jurnal Pendidikan dan Pembelajaran Vol (21) No. 2.

Hutapea, Bonar. 2011. Emotional Intelegence dan Psychological Well-being pada Manusia Lanjut Usia Anggota Organisasi Berbasis Keagamaan di Jakarta. Jakarta : Fakultas Psikologi Universitas Persada Indonesia. Vol. (13) No. 02

Mailisa dan Khairani. 2017. Gambaran Psychological Well-Being Pada Lansia Di Panti Werdha. Banda Aceh : Program Studi Ilmu Keperawatan Fakultas Keperawatan Universitas Syiah Kuala.

Ningsih, K \& Karyanti. Keefektivan Cinema-Education Pada Pelatihan Ketrerampilan Pengambilan Keputusan Karier Pada Peserta. Jurnal Bimbingan dan Konseling Vol (3) No. 1 
Nurzainun. 2018. Indonesia dalam Ancaman Ledakan Penduduk. Jurnal Keluarga Vol (4) No. 5.

Pertiwi, Suryani Wandari Putri. 2020. Tahun Ini, Jumlah Lansia 10,6\% dari Populasi Indonesia (https://mediaindonesia.com/read/detail/346598-tahun-ini-jumlahlansia-106-dari-populasi-indonesia (diakses 21 Oktober 2020)

Rahmawati, Pudji. 2014. Media Bimbingan dan Konseling. Surabaya: CV. Cahaya Intan. Tomb, David A. 2003. Buku Panduan Psikiatri Edisi 6. Jakarta: EGC.

Sapiana. 2014. Pengaruh Bimbingan Kelompok Teknik Cinema Therapy Terhadap Motivasi Belajar Siswa Kelas X Multimedia Di SMK Negeri 1 Limboto Kabupaten Gorontalo. Gorontalo : Other Thesis Universitas Negeri Gorontalo.

Sugiyono. 2017. Statistik Untuk Penelitian. Bandung : Alfabeta 2015. Metode Penelitian Kuantitatif, Kualitatif, dan R\&D. Bandung: Alfabeta

Wolz, Birgit. 2004. E-motion Picture Magic A Movie Lovers Guide To Healing Transformations. Colorado: Glenbridge Publishing. 